\title{
Implementation of Muhammadiyah Cultural Da'wah In the Education Sector in Palu City
}

\author{
S Kadir ${ }^{1}$, Nuranisa1, Gazali ${ }^{2}$, A. Asikin ${ }^{3}$, E. Mulyadi ${ }^{4}$ \\ \{surnikadir2@gmail.com ${ }^{1}$, nonaanisa51@gmail.com ${ }^{2}$, miftahgzali@gmail.com ${ }^{3}$, \\ ernitasarim@yahoo.com $\left.{ }^{4}\right\}$ \\ Faculty of Teacher Training and Education, English Department, Universitas Muhammadiyah Palu, \\ Centra Sulawesi 94118, Indonesia ${ }^{1,2,3}$ \\ Faculty of Islamic Studies, Universitas Muhammadiyah Palu, Central Sulawesi 94118, \\ Indonesia ${ }^{4}$
}

\begin{abstract}
The presence of Muhammadiyah is theologically inherent and inspirational to the Kaili ethnic community who have embraced Islam because of Muhammadiyah's tajdid teachings, but sociologically at the same time it has a context that Muslims of Kaili tribe back in that time were still left behind. Muhammadiyah does pioneered the presence of authentic (pure) Islam and is oriented towards progress in its reformation, which directs the lives of the Muslim community of the Kaili tribe to be religious in a correct manner as well as a grace. The method in this research is qualitative descriptive method to produce descriptive data in form of written or oral data from respondents or actors observed. Method in this research is carried out by studying the literature from a number of books and relevant journals. Data were obtained through literature studies to make a descriptive analysis of the focus of the research on the Implementation of Muhammadiyah Cultural da'wahin the Education Sector in Palu City. The result of the research reveals that the role of Muhammadiyah Cultural da'wah in Palu City, especially in the sector of education brought significant changes since the land of Kaili formed in 1932 until now. Central character played by the figure of Rusdy Toana has been able to change the mindset of the Kaili people from adolescence to enlightenment. Muhammadiyah, has succeeded in supporting the Kaili Tribe community in the sectors of Education, Social, Religious Affairs, and Health. In the sector of education, Muhammadiyah has succeeded in establishing schools, such as: 11 Kindergartens, 5 Elementary Schools, 5 Junior High Schools, 4 Senior High Schools and 1 Higher Education with 8 Faculties plus 2 Post-graduates. Cultural da'wah in education sector is a mission to stay away from radical attitudes as an effort to realize Islam Rohmatan lil ' alamin.
\end{abstract}

Keywords: Cultural Da'wah, Muhammadiyah, Education

\section{Introduction}

This Word document can be used as a template for papers to be published in EAI Core Proceedings. Follow the text for further instructions on text formating, tables, figures, citations and references. 


\section{Introduction}

Vision in implementing Muhammadiyah education is to organize effective management and education networks as an advanced, professional and modern Islamic movement and to lay a solid foundation for improving the quality of Muhammadiyah education. The mission of implementing Muhammadiyah education according to (Nelly Yusra: 2018 (1) is: (1) upholding the pure belief in monotheism, (2) disseminating Islamic teachings from the Qoran and as-Sunnah, (3) realizing Islamic deeds in personal life, family and community, (4) making Muhammadiyah educational institutions the center of education, da'wah and cadre. Muhammadiyah primary and secondary education principles are based on Islam which is based on the Qoran and al-Sunnah. Meanwhile, Muhammadiyah primary and secondary education aims is to develop various potentials of students to become human beings who believe in and have devotion to Allah SWT, noble, healthy, knowledgeable, creative, independent, democratic and responsible citizens of Indonesia for the realization of a truly Islamic society. Muhammadiyah throughout Indonesia in 2006. (1).

Supporting factors for the presence of Muhammadiyah in general is originated through some social, religious and moral anxieties and concerns. This social anxiety occurs due to ignorance, poverty and backwardness of people. Religious anxiety arises from seeing a mechanistic religious practice with no visible link to positive social behavior, as well as being laden with superstitions, bid ah and khurafat. Moral anxiety is caused by blurring the boundaries between good and bad, appropriate and inappropriate. Apart from being a socioreligious movement, the Muhammadiyah organization is also known as the tajdid movement..

Even though Muhammadiyah's approach varies according to its activities, Muhammadiyah itself calls as an Islamic movement and the da'wah of amar makruf nahi munkar, which has Islamic beliefs sourced from the Qoran and as-sunnah. Therefore, Muhammadiyah has an identity: the Islamic movement, the da'wah movement of amar makruf nahi munkar, and the movement with Islamic beliefs and originating from the Qoran and the Sunnah. This identity has implications for the space and activities in multi-aspects of life, according to the needs of humans or society. (2)

Muhammadiyah as one of the largest socio-religious organizations in the country has entered at the second century. One of the challenges faced by Muhammadiyah was finding the right formulation to disentangle the relationship between religion and culture. Muhammadiyah debates the relationship between religion and culture on strategic discourse and the implementation of the concept of cultural da'wah. Cultural da'wah will be discussed in a more operational context. This shows how strong the internal desire of Muhammadiyah to change the da'wah strategy by accommodating more local traditions, culture and customs. The da'wah strategy by adjusting variety of religious life as a socio-cultural process is hereinafter popularly referred to cultural da'wah. (3).

Da'wah must be present in the efforts to enlight, to develop, to empower people. Because in essence da'wah is not only a process of introducing humans to their God, but also a process of social transformation, with a number of offers and alternative solutions for people in overcoming life problems they face. (4)..

Da'wah is also a process of social transformation, as well as the comprehensive strategies and approaches that were developed by Rasulullah Saw when designing and mobilizing programs and agenda which contains the development or empowerment of the community and has a liberation perspective. In order to carry out such da'wah, the preachers must understand four main pillars of the da'wah approach strategy properly, as has been offered by Syukriadi Sambas, namely tabligh and ta'lim, irshad, tadbir, and tathwir. (5) 
The cultural da'wah of Muhammadiyah in essence which is concerned with local culture is more centered on the elements of the activity system of culture, because this aspect is the most tangible and widespread cultural feature of society, apart from ideas and physical aspects. Therefore, it is necessary to choose the form of cultural activities to be used as media and targets of da'wah. In this connection, both furification and dynamism (renewal) can go hand in hand as a unity of ideas and actions from the cultural da'wah movement. (6).

Muhammadiyah is seen as having a very important role in spreading the ideas of Islamic renewal and having a very strong influence among the Indonesian middle class. Muhammadiyah can be said as a trendsetter and can be likened to a pulling locomotive for the carriages Indonesian reformist movement. This can be seen through the wide scope of Muhammadiyah reforms that are not only engaged in the level of educational reform but also in various other sectors such as pioneering the establishment of orphanages, hospitals, People's Credit Banks, Baitul Mal wa at-Tamwil and others as a characteristic of modern society. (1).

\section{Literature Review}

Muh. Syamsuddin: 2017 in a journal Muhammadiyah Movement in Grounding Multiculturalism Discourse a Normative-Institutional Foundation, that discursivity about the phenomenon of multiculturalism within Muhammadiyah is relatively recent. The climax was when there was a Tanwir session in Denpasar Bali in 2002. a big idea emerged about what is called "cultural da'wah" from a lengthy discussion involving a number of central administrators, academics, and representatives of the Muhammadiyah Regional Leadership, in the session. figures such as Kuntowijoyo, Abdul Munir Mulkhan, and Amin Abdullah provides their apreciative notes. (3)

ST Rajiah Rusydi; 2018, Muhammadiyah Education Concept, that Muhammadiyah Education and Teaching Muhammadiyah education as a professional charity has been implemented by K.H. Ahmad Dahlan and the founding fathers of Muhammadiyah education. The development of Muhammadiyah education is able to carry out the concept of professional good deeds.

The establishment of Muhammadiyah education was based on the theological motivation that humans would be able to achieve a perfect degree of faith and devotion if they had the depth of knowledge. The Qoran very broadly explains the difference between those who are knowledgeable and those who are ignorant, those who are guided and lost. Humans will have high dignity if they have the depth of faith and the breadth of knowledge (Surah AlMujadalah: 11). Fearful faith will only be achieved by those who are knowledgeable (Surah Fathir: 28; Surah Az-Zumar: 9).

Theological motivation drives K.H. Ahmad Dahlan to provide education in the patio of his house and provides extra-curricular religious lessons at OSVIA and Kweekschool. K.H.'s actions Ahmad Dahlan organized this religious education as a form of shalib charity. Arifin (1987) in the Muhammadiyah Renewal Idea explained that as a result of Dutch colonialism, the Muslim community - and the Indonesian in general experienced two very acute educational problems. Departing from this reality, K.H. Ahmad Dahlan founded Muhammadiyah education in which religious and general subjects were taught. This Muhammadiyah education model is a combination of the Dutch model school system and the pesantren/boarding school. Muhammadiyah education is expected to be able to produce "ulama-intellectuals" or "intellectuals"; the "whole" generation is not the generation that 
experiences "split personality." Religion, in the view of K.H. Ahmad Dahlan, must be in line and support each other with science. The existence of Muhammadiyah education at that time was a form of good deeds. K.H. Ahmad Dahlan was able to offer a new educational model as an embodiment (ashlah) from the conventional education of Dutch schools and Islamic boarding schools. Muhammadiyah education is also able to have "more perfect" generation than the alumni of Dutch pesantren and schools. (7) From an educational perspective, the precense of Muhammadiyah is partly due to the dualism of the education system. First, there was a colonial education system (Dutch education) which was schuralistic and discriminatory. It is said to be schuralistic because they only studied general knowledge and put religious knowledge aside. The education carried out by the Dutch colonial was also discriminatory. This means that not everyone can follow the education implemented by the colonial schools. However, the educational system managed by the colony was modern. (8)

Surni Kadir: 2020 in the IJICC journal "Framing Kaili Tribe Culture in the Muhammadiyah Education Perspective," concludes that, the presence of Muhammadiyah in the land of Kaili is a pure and progressive Islamic movement presented not through individual channels, but an organizational system. Presenting an Islamic movement through an organization was a breakthrough at that time, when the Kaili people were still framed by a traditional culture that relied more on beliefs in anism and dynamism. The Muhammadiyah movement was a phenomenon at that time for the Kaili tribe community because Muhammadiyah in its renewal concept wanted to restore pure Islamic teachings based on the Al-Qur'an and the Sunnah of the Prophet who had to adapt to the original beliefs of the Kaili tribe community which were sourced from the teachings of their ancestors. The essence of da'wah in this case is to create and to provide direction for change. Changing the social and cultural conditions from injustice to justice, ignorance to progress-intelligence, poverty to prosperity, underdevelopment towards progress, change, improvement and development. This is in line with the history of the presence of Islam, with his da'wah the Prophet was able to move fundamental social changes from the era of ignorance to the era of Islam with all the dynamics of civilization. (9)

Based on some of the research results mentioned above, it can be concluded that Muhammadiyah cultural da'wah, especially in the sector of urgent education, is needed in the midst of society as an answer that Muhammadiyah carries out the mission of da'wah amar ma'ruf nahi munkar.

\section{Method}

This is descriptive qualitative research which the approach is based on phenomenology and constructivism paradigm in developing knowledge. This method reveals descriptive data in form of written or spoken/verbal from the respondents observed through literature study, books and relevant journals. Data were collected through literature study used to make the descriptive analysis towards research focus on the Implementation of Da'wah Culture of Muhammadiyah in the Field of Education in Palu city. The qualitative research is deepened regarding to social phenomenon or social environment such as behavior, phenomena, place, and time. Moreover, the social background is described fully in expectation that the researcher is able to develop basic questions such as what and how the phenomena happened, who is involved, when and where it is happened. 


\section{Results and Discussion}

The researcher through this paper, would like to present the findings regarding the implementation of Muhammadiyah cultural da'wah in the education sector in Palu City, based on the results of research that has been carried out as follows.

\subsection{Implications of the presence of Muammadiyah in Palu}

The presence of Muhammadiyah in Tanah Kaili is a new phenomenon that appears to be prominent from the pure and progressive Islamic movement that is presented not through individual channels, but through an organizational system. Presenting an Islamic movement through an organization was a breakthrough at that time, when the Kaili people were still framed by a traditional culture that relied more on beliefs in anism and dynamism. The Muhammadiyah movement was a phenomenon at that time for the Kaili tribe community because Muhammadiyah in its renewal concept wanted to restore pure Islamic teachings based on the Al-Qur'an and the Prophet's Sunnah, which was authentic, had to adapt to the original beliefs of the Kaili tribe community which were derived from the teachings of their ancestors. (10).

Muhammadiyah with the inspiration of Al-Qur'an Surat Ali Imran 104 wants to present Islam not only as a "transcendent" teaching that invites awareness of faith within the framework of tauhid alone. It is not just pure Islam, but does not care about life. Moreover, pure Islam is only partially understood. However, furthermore Islam is shown as a dynamic force for social transformation in the real world of humanity through the "humanization" movement (inviting all goodness), to follow the Qur'an and the sunnah of the Prophet. (11) (11) (11) ( 11) (10) (11) (10).

\subsection{Da'wah of Muhammadiyah in education sector in Palu}

The forms of Muhammadiyah charity efforts in Palu City since its establishment in 1932 in the sector of Education are as follows. In the sector of education, it is hoped that Muhammadiyah in Palu City can continue to produce national cadres, who own qualified Islamic insight, to build better Indonesian nation in the future.The charities in the education sector that have spread throughout the city of Palu include the following:

1. Kindergarteen are,TK ABA 1 to TK ABA 11 in Palu.

2. Elementary School Level / MI sbb :

- MI Muhammadiyah Nunu ; St. Kalora No. 22

- MI Al- Haq ; St.Suprapto No. 69

- SD Muhammadiyah 1 Lere : St.Tompi

- SD Muhammadiyah Ujuna : St.S. Wera

- MI Aisyiyah : St.Hangtuah

3. Junior High School Level/ MTs sbb :

- MTs.Muh. Nunu : St.Kalora No. 22

- MTs.Putri Aisyiah : St.Hangtuah

- MTs. Muh.Al-Hak : St. Suprapto No. 69 
- SMP Muh. Lere $\quad$ :St.. Tompi

-. SMP LB Muh : St.Tompi

4. Senior High School Level/MAN sbb :

- MA Muh. Nunu : : St..Kalora No. 22

- MA Putri Aisyiyah : St.Hangtuah

- SMK Muh 1 : St.Soeprapto No. 69 Palu

- SMA Muh. Palu : St.Soeprapto No. 69 Palu

5. Faculties in Muhammadiyah University Palu :

- Master of Management in Islamic Education: St.Jabal Nur 01

- Master of Law: St. Hangtuah No. 114

- Faculty of Islamic Religion

- Faculty of Public Health

- Faculty of Education and Teacher Training

- Faculty of Law

- Faculty of Social and Political Sciences

- Faculty of Engineering

- Faculty of Agriculture

- Faculty of Economics. (13)

Muhammadiyah figures who have changed the nature of thinking of the Kaili tribe, they are as follows

1. Yandi Maranua, a Muhammadiyah figure who has changed traditions or culture such as the Balia, Pompaura ceremonies and others that reek of animism and dynamism in the Tavaili community, towards purifying Islamic teachings based on the Al-Qur'an and Hadith.

2. Yunus Sunusi; Peodal society, in the kingdom of Tavaili changes in idolatrous culture.

3. H.M. Ridwan; the power of faith and the development of knowledge (Purification of Tauhid), eliminating the culture of cultizing a person.

4. H. Rusdy Toana; A Muhammadiyah figure who is engaged in the socio-political and religious sectors, control government areas, one of the concrete efforts that have been made is the establishment of the Muhammadiyah College and the daily newspaper Mercusuar in Palu.

5. H. Tjatjo Thaha; Da'wah through education, reinforces Muhammadiyah beliefs through education.

6. Isak Arif: Da'wah for Moral Improvement through Education, one of his real efforts is to establish Al-Istiqamah Modern Islamic Boarding School in Ngatabaru, Palu.

Syamsuddin H. Khalid, Modern Management Systems towards rational thinking. (10) In fostering a business with self-help initiatives and community funds itself, it cannot be denied that joy and sorrow come and go and vary so that KH's message is remembered. Ahmad Dahlan "Long live Muhammadiyah and don't make a living in Muhammadiyah". Because

\subsection{Analysis of the role of Muhammadiyah da'wah in the education sector in Palu}

Muhammadiyah with various activities carried out in Palu shows how serious this organization is in developing its potential. The number of charitable businesses that are 
successfully managed shows the ability of the Muhammadiyah organization to carry out its potential. In education sector, for example, Muhammadiyah has succeeded in establishing schools starting from the Kindergarten Level to Higher Education. Even charity businesses in education sector and can be said to have broad access in the midst of society.

There are several factors that need to be considered in formulating a strategy, furthermore the strategy can actually lead the organization towards predetermined goals. Among the factors that need to be considered are: First Idiology, Second content, Third Mission, Fourth, effort or task pattern, the fifth environment, both external and internal. (12) Dewey views the individual as something functional in social life. Every individual in the view of progressivism is an organism that experiences a process. Because each individual is an integral part of the environment, events that occur in society, social interactions, feelings, thoughts and objects around them. If the learning environment is peaceful, pleasant, full of tolerance, then these conditions have an impact on the learning experience and psychological condition that each individual gets. (14)

Surni Kadir: 2018, Muhammadiyah cultural da'wah is built on three main pillars, namely: First, da'wah is enlightenment-oriented, secondly da'wah is oriented towards intelligence, and the third is da'wah that is oriented towards exemplary orientation. (9)

\section{Da'wah oriented towards intelligence}

Muhammadiyah organization in Palu affirms its presence as a mujaddid, reformer, cleanser from various superstitions, heresy, and khurafat and various Islamic amaliyah which are considered 'not straight'. The presence Muhammadiyah da'wah in Central Sulawesi, especially the city of Palu, in one and another case, touching or dealing with the da'wah role of three other Islamic organizations, namely (NU, Alkhaerat and DDI) which emphasized the character of Ahlussunnah wal Jamaah that had entered and 'controlled' Palu City first. This contact often causes conflict in the past at the early days of Muhammadiyah's established. Furthermore, other than verbal da'wah and religious lectures, da'wah bil qolam with various books and Muhammadiyah brochures, especially all Muhammadiyah charities are a manifestation of Islamic bil hal da'wah. The material he conveyed was Islamic teachings from the Al-Quran and Sunnah which in a certain format became the material for Al-Islam Muhammadiyah. For example, this is conveyed at all levels of education belonging to Muhammadiyah as a compulsory subject or subject for all its students.

Muhammadiyah Da'wah covers Da'wah for verbal bill, bill qolam, and bill hal. The da'wah verbal bil is carried out by religious lectures in the community, discussions at government agencies / offices, forum, and mosques; active inter dialogues on Radio and lectures on Safari Ramadan. Da'wah bil qolam is carried out by publishing the Mercusuar newspaper that was initiated by the late. H. Rusdy Toana. Meanwhile, da'wah bil hal is done in a variety of programs, starting from building economic enterprises, building Siti Fadilah Hospital, to various levels of education lines.

Based on the description above, the Management of Muhammadiyah and Aisyiah in Central Sulawesi Province, especially the city of Palu, have carried out many activities of da'wah to educate the ummah, either directly or indirectly through culture, and Aisyiyah Central Sulawesi Province that committed to orienting itself towards educating the nation, and Aisyiyah as Da'wah organizations that carry forward women's missions. The goal is to educate the nation, including to activate the reading and writing movement with the establishment of the library park movement in branches, regions and charities in the field of education as described above. Routine recitation activities carried out by Muhammadiyah and Aisyiah administrators are as follows: 
- The Muhammadiyah / Aisyiah Leadership Study once a week is held in Muhammadiyah mosques, the study material is in the HPT regarding the latest information such as the procedures for worshiping etc.

- The recitation is routinely carried out by the Majelis Tablih Muhammadiyah and Aisyiyah once a month. The recitation is carried out by the branch level, there are several branches respectively.

- Baitul Aram for the management of Muhammadiyah charities by providing Muhammadiyah strengthening. The Dikdasmen Council (Primary and Secondary Education) implements Baitu Aram from the principal level to the service clan. As a prerequisite for joining a business practice, Baitul arqam Muhammadiyah teachers in the charity environment.

- Exciting art as a means of da'wah (Cultural institutions explore local culture combined with Islamic values. For example, in the TKTK, by releasing Islamic songs, the transfer of Islamic values, Islamic tales, and Islamic dances.

- Recitation students parents, both at the kindergarten to high school level, is held once a month by inviting all parents of students at all levels to participate in the activity.

\section{Enlightenment-oriented Da'wah}

Da'wah oriented towards intelligence includes in 3 activities, namely: First, invite people to accept Islamic guidance and increase the level of faith and devotion. Delivering Islamic teachings to all mankind anytime and anywhere. Second, Amar Maruf Nahi Munakar, trying to encourage and mobilize the ummah in good things includes various efforts that bring human benefit to all aspects of life, both in the social, cultural, political and economic fields. All areas of life must be mobilized for the benefit and welfare of human life.Third, Encourage and move human race to reject and leave evil things. It also eliminates all forms of evil that consoder as diseases in society. Da'wah of enlightenment-oriented, focuses on recitation (both from the branch to the regional level because that is the heart of the organization, this recitation movement is a hallmark of the existence of Muhammadiyah and Aisyiah in Palu. Muhammadiyah and Aisyiyah never get tired to give enlightenment da'wah that fill religious spirit so that bias does not occur and provide enlightenment to all people in ways that are in accordance with the spirit of Islamic teachings.

\section{Model-oriented da'wah}

A da'i should not just convey religious teachings without practicing them. Da'i should be the first to practice what he says. The ability of the da'i to become a real example of his people in acting is a wisdom that should not be abandoned. Real practice means that is immediately seen by the community, the preachers are not too difficult to talk a lot, but their movements are da'wah which is far more effective than just speaking. (15)

Muhammadiyah is an organization whose main mission is to do da'wah of amar maruf and nahi munkar, so its main target is to frame the Pumpura culture of the Kaili tribe community with pure Islamic teaching frame based on the Al-Qur'an and Sunnah of the Prophet, Muhammadiyah will target da'wah for several areas in the city. Palu, which is still staunchly defending the pumpura culture, maps out the targets of da'wah and the potentials that are targeted for the guidance of the ummah, which provides enlightenment for the Kaili tribe community in Palu. (16) 


\section{Conclusion}

Theologically the Kaili tribe community, inspired by the presence of Muhammadiyah in Palu which is inherent and has an appeal to people who have embraced Islam because Muhammadiyah teachings is tajdid. Moreover, sociologically at the same time it has a context with the living conditions of the Kaili tribe's Muslims that were still left behind back in that time. Muhammadiyah has pioneered the presence of authentic (pure) Islam and is oriented towards progress in its reformation. It directs the lives of Muslim community of the Kaili tribe to be religious in a correct manner and bring grace to their life. The role of the Da'wah of Muhammadiyah in Palu City, especially in education sector, since its establishment in the land of Kaili in 1932 until now has been felt to have brought significant changes. The central character played by the figure of Rusdy Toana has been able to change the mindset of the Kaili people from adolescence to enlightenment. Muhammadiyah, has succeeded in supporting the Kaili Tribe community in Education education, Social, Religious Affairs, and Health. Muhammadiyah has succeeded in establishing schools, namely 11 Kindergartens, 5 Elementary Schools, 5 Junior High Schools, 4 Senior High Schools and 1 Higher Education with 8 Faculties plus 2 Post-graduates. Cultural da'wah in education is a mission to stay away from radical attitudes as an effort to realize Islam Rohmatan lil ' alamin.

\section{References}

[1] Yusra N, Vebrianto R. Berbasis Multiple Intelligences Theory ( MIT ). AL-USWAH J Ris dan Kaji Pendidik Agama Islam. 2019;1(2):112-28

[2] Zain A, Yusuf M, Fuadi M. Internalisasi Nilai-Nilai Modernitas Dalam Gerakan Dakwah Organisasi Muhammadiyah Di Aceh. Al-Idarah J Manaj dan Adm Islam. 2017;1(1):17

[3] Syamsuddin M. Gerakan Muhammadiyah Dalam Membumikan Wacana Multikulturalisme: Sebuah Landasan Normatif-Institusional. J Pemberdaya Masy Media Pemikir dan Dakwah Pembang. 2018;1(2):361.

[4] Jamalie Z. Pola Dakwah Pada "Masyarakat Suku Terasing” Di Kalimantan Selatan. J Dakwah [Internet]. 2017;16(1):1-18. Available from: http://ejournal.uinsuka.ac.id/dakwah/jurnaldakwah/article/view/1059.

[5] Muhyidin A, Solihati N, Hamidiyah A, Senjaya A. Reference grammatical cohesion in a literary text and its application to language learning in high school. Int $\mathrm{J}$ Innov Creat Chang. 2020;12(6):27-44.

[6] Pimpinan Pusat Muhammadiyah. No Title. cetakan ke. Pimpinan Pusat Muhammadiyah, editor. Yogyakarta; 2016.

[7] Rusydi R. Peran Muhammadiyah ( Konsep Pendidikan, Usaha-Usaha Di Bidang Pendidikan, Dan Tokoh). TARBAWI J Pendidik Agama Islam. 2017;1(2):139-48

[8] Sutarto S, Sari DP, Anrial A. Kiprah Muhammadiyah Dalam Pembaharuan Pendidikan dan Sosial Keagamaan di Nusantara: Kajian Terhadap Pemikiran KH. Ahmad Dahlan. Belajea; J Pendidik Islam. 2020;5(1):1.

[9] Kadir S, Normawati, Halik A. Framing kaili tribe culture in the Muhammadiyah education perspective. Int J Innov Creat Chang. 2020;12(6):108-22.

[10] Kadir S. POLA AKULTURASI ISLAM DAN BUDAYA POMPAURA. 2018;2(1):131-51 
[11] Katsir Ibnu. No Title [Internet]. Keenam, editor. Bandung: Ibnu Katsir; 2020. 621 p. Available from: penerbit_jabal@yahoo.com.

[12] Sholeh Rosyad. No Title [Internet]. IV. Rosyad S, editor. Yogyakarta: Suara Muhammadiyah; 2017. 289 p. Available from: penerbitsm@gmail.com.

[13] Palu LAKM. 1 Laporan Akhir-Surni Kadir-Universitas Muhammadiyah Palu -2019. 2020;1-92.

[14] Saihu S. Pendidikan Karakter Berbasis Kearifan Lokal (Studi Di Jembrana Bali). Edukasi Islam J Pendidik Islam. 2019;8(01):69.

[15] Rafdeadi R. Keteladanan Dakwah Di Tengah Masyarakat Multikultural. Risalah. 2013;23(1):1-11

[16] Masdul MR, Kadir S. قأ 2016;11(2):19-38. 